\title{
Constructed Wetland: A Solution for Wastewater Treatment
}

\author{
Dibesh Shrestha and Shovana Maharjan
}

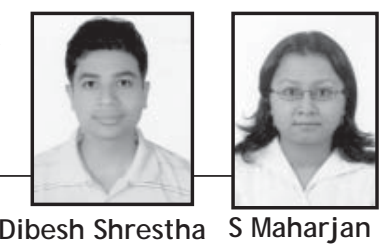

Abstract: Due to population explosion, rapid industrialization and urbanization, Nepal's limited source of water is polluted (especially in the Kathmandu Valley). The quality of water is vital concern, as it is directly linked with human welfare. The water that we use for our survival should be potable, clean, and free of impurities. To mitigate the problem of water pollution, low-cost natural treatment options like Constructed Wetlands (CW) and the related Reed Bed Treatment System (RBT) have been introduced in Nepal in several places like hospitals, universities and other institutions, and as community systems. The plant species Phragmites karka is used in this process. It, and other associated micro organisms removes contaminates from wastewater using a natural process. Compared to other large and expensive technologies, CW and RBT require less land and are less expensive for construction, operation and maintenance. Hence, they can be considered as effective, economic and environmentally friendly and sustainable systems for wastewater treatment.

Keywords: Wastewater treatment, constructed wetlands (CW), reed bed treatment (RBT), Nepal

\section{Introduction:} The total water quantity on earth is constant and
is recycled by nature in the atmosphere, on the earth's surface, below the surface and in the oceans. Population explosion, rapid industrialization and consequent urbanization have increased the demand for required quantity of water for different end users. Over recent decades, Man has been solely responsible for contaminating the sources of water by neglecting to control the pollution of water. The Kathmandu valley can be taken as the excellent example that is facing the serious water pollution problems. It is estimated that total sewage production of the valley is approximately 124 million liters per day (MLD). The estimated population of the Kathmandu valley is 2.2 million. With 80 liters/ day per person wastewater produced, about 176 MLD of waste water is generated from Kathmandu valley of which major portion is of domestic origion.

The major sources of water pollution are domestic waste discharged into natural water bodies from households, commercial sectors and industrial sectors, due to which there is always a shortage of clean drinking and inadequate and inappropriate sanitation facilities thus causing pollution of water bodies. It is necessary, therefore, to have treatment of wastewater before it is released into the environment. This treatment technology should be of simple construction, should work efficiently, be preferably of low in cost and easy to maintain. Appropriate treatment and disposal is a prerequisite to avoiding the development of conditions that may endanger public health and welfare. One of the best

\section{Sunga Wastewater Treatment Plant: A Perfect Example}

Begin its operation since October 2005, Sunga Wastewater Treatment plant was designed by ENPHO, established with financial support from Asian Development Bank (ADB), UN-HABITAT and Water Aid Nepal (WAN). This is the only community based Reed Bed System or Constructed Wetland in Nepal designed to treat the wastewater of about 1200 population from 200 households of Madhyapur Thimi Municipality in Nepal but it is currently treating wastewater from 80 households only. The plant bed consists of a three-chambered anaerobic baffle reactor with a capacity of treating $42 \mathrm{~m}^{3}$ of load as primary treatment unit. Second treatment unit consists two horizontal flow reed beds followed by two vertical flow reed beds with total area of $150 \mathrm{~m}^{2}$ respectively and provided with a sludge drying bed with an area of $55 \mathrm{~m}^{2}$. The total capacity of the plant is $50 \mathrm{~m}^{3}$ of wastewater per day. The municipality provided land for plant and has been providing financial assistance for its operation and maintenance. The support from local community reflects that construction of such treatment plants at other locationsis theneed of day and only then the problem of waste water management can be efficiently reduced.

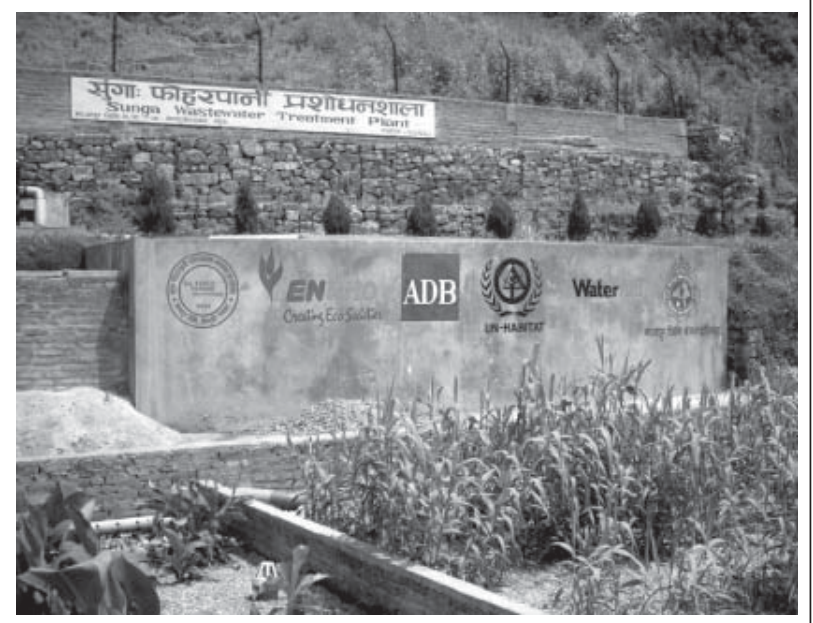

CW at Sunga Wastewater Treatment Plant 
methods is the development of constructed wetland.

\section{What is constructed wetland?}

Constructed wetland (CW) is a biological wastewater treatment technology based on natural processes found in natural wetland ecosystem. It is also known as reed bed technology. Because constructed wetland systems are designed specifically for wastewater treatment, they typically work more efficiently than natural wetlands.

CW is shallow basin filled with some sort of filter material (substrate), usually sand or gravel, and planted with vegetation tolerant of saturated conditions. The most common vegetation used in CW systems is Phragmites karka. Waste water is introduced into the basin and flows over the surface or through the substrate, then is discharged out of the basin through a structure which controls the depth of wastewater in the wetland. CWs are designed to take advantage of many of the same processes that occur in natural wetlands, but do so within a more controlled environment. Some of these systems can be designed and operated with the sole purpose of treating wastewater; or, they can be designed and implemented with multiple use objectives in mind.

\section{Constructed Wetlands in Nepal}

The Environment and Public Health Organization (ENPHO), a Nepalese national non-governmental organization (NGO), has introduced a CW technology as a low cost, decentralized and effective option for wastewater treatment and recycling in Nepal. In 1997, the first CW was built at the Dhulikhel Hospital under design and technical supervision of Nepalese and Austrian researchers from the

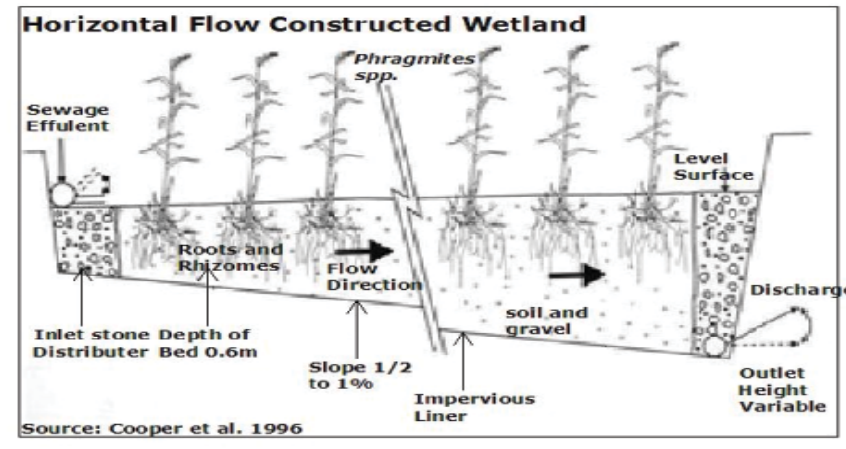

Figure 1. Horizontal Flow CW

University of Natural Resources and Applied Life Science (BOKU), in Vienna. Following thesuccessful demonstration of CW technology at the Dhulikhel Hospital, the technology has been replicated at several other places.

Today there are 11 sub-surface flow CW systems in operation for the treatment of grey water, wastewater and fecal sludge at various scales in Nepal. Treatment systems range from the single household level to institutions with more than 300 inhabitants. The Nepal government has also decided to install CW system at eight small cities for treatment of municipal wastewater under the Urban Environment Improvement Program funded by Asian Development Bank (ADB). ENPHO is carrying out the performance evaluation. On the basis of past six years of experience with CW, ENPHO has found high pollutant removal efficiency with more than $95 \%$ of major pollutants such as suspended solids, organic pollutants, ammonianitrogen are removed.

\section{What does CW do?}

Vegetation plays a vital role in wetlands, as they provide surfaces and a suitable environment for microbial growth and filtration. Pollutants are removed within the wetlands by several complex physical, chemical and biological processes.

Wastewater from sewers is passed into a septic tank or anaerobic baffle reactor (like a septic tank with multiple compartments separated by baffle walls) for preliminary treatment. Settleable suspended solids that are not removed in the primary treatment are effectively removed in the wetland by filtration and sedimentation. Particles that settle into stagnant micro pockets are stained by flow constrictions. Attached and suspended microbial growth is responsible for the removal of soluble organic compounds, which are degraded biologically both aerobically (in presence of dissolved oxygen) as well as anerobically (in absence of dissolved oxygen). The oxygen required for aerobic degradation is supplied directly from the atmosphere by diffusion or oxygen leakage from the vegetation roots into the rhizosphere; the oxygen transfer from the roots, however, is negligible.

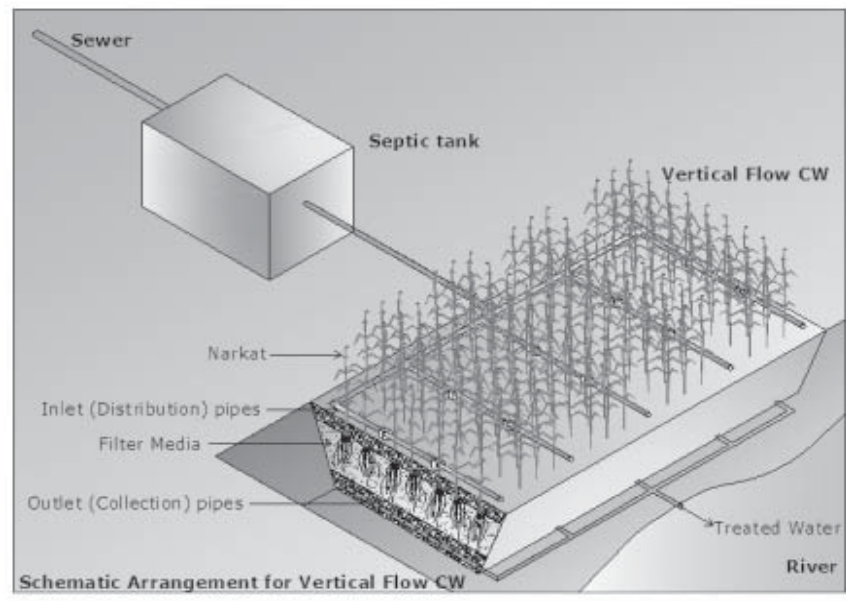

Figure 2. Vertical Flow CW

The mechanism for the phosphorus removal in constructed wetlands is adsorption, complexation and precipitation, storage, plant uptake and biotic assimilation. The removal mechanisms for nitrogen are manifold and include volatilization, ammonification, nitrification/ denitrification, plant uptake and matrix adsorption. The major removal mechanism in most of the constructed wetlands is microbial nitrification/denitrification. Ammonia is oxidized to nitrate by nitrifying bacteria in aerobic zones. Nitrates are converted to dinitrogen gas by denitrifying bacteria in anoxic and anerobic zones.

The process of metal removal in CWs include sedimentation, filtration, adsorption, complexation, 
precipitation, cation exchange, plant uptake and microbially-mediated reactions especially oxidation. Adsorption involves the binding of metal ions to plant or matrix surface, whereas the presence of bacteria causes the precipitation of metal oxides and sulphides within the wetland. Some wetland species have a well-established ability for direct uptake of metals.

\section{Technology}

Wastewater from sewer is passed into a septic tank or anaerobic baffle reactor (like septic tanks with multiple compartments separated by baffle walls) for preliminary treatment. Effluent (resulting wastewater) is transported through pipelines and is applied to the basin via an inlet arrangement. Wastewater flows over (free water surfaceFWS CW) or through the filter media. The filter media include suitable sized sand and gravels under gravity (subsurface flow-SSF CW)) either by horizontal movement (Horizontal flow CW) or vertical movement (Vertical flow CW). The filter media supports the growth of vegetation like Phragmites karka (narkat in Nepali). Wastewater passes through the aerobic zone at the roots of the vegetation and anaerobic zone formed between the particles of filter media. The bed is on a slope, and is lined with an impervious material such as plastic to prevent infiltration of wastewater into the ground. The outlet is designed to collect the treated water and discharge it out of the basin. The treated water can be used for fisheries, or gardening, or can be discharged into the river.

On average $1.6 \mathrm{~m}^{2}$ area of constructed wetland is required for treating the waste of one person per day. Approximately $14.5 \mathrm{~m}^{2}$ of land is required to treat unit flow (cubic meter per day). Studies conducted at Dhulikhel Hospital and Malpi International School show that at both institutions $4 \mathrm{~m}^{2}$ of land (bed area) are required to treat one cubic meter of wastewater per day. This was found to be less than our assumption of seven to $10 \mathrm{~m}^{2}$ to treat one cubic meter of wastewater. Comparatively, Bhattarai, Khatiwada and Sharma (2006) estimate $0.2 \mathrm{~m}^{2}$ of land is required to treat wastewater generated by one person per day. Nature and quality of the wastewater and type of pretreatment all play important roles in determining the size of the constructed wetland.

\section{Feasibility in context of the urban household and Kathmandu valley}

Thebasicneed of a constructed wetland island. Wherethere is shortage of land, as in an urban core where land has high monetary value, people prefer not to use land for purposes other than building construction and sales. Between 60 to 170 sq. $\mathrm{ft}$ of land is sufficient to treat wastewater from a household comprised of six to 10 members. A private residence at KMC Ward 15 uses 6 sq. $\mathrm{m}$ of land for eight household members.

Sand filters also can be used to treat the grey water. Treated water after disinfection can be reused for various purposes; e.g., for drinking, lawn-watering or car washing, depending upon the degree of treatment. Since, CW allows reusing the water, thus saves water. This type of wastewater treatment in houses and institutions can minimize water pollution in places like the Kathmandu valley. A municipalor community-based CW treatment plant can treat a high amount of wastewater before discharging it into rivers. An excellent example in Nepal is the Community Based Sunga Wastewater Treatment Plant at Thimi Municipality, near Kathmandu (see box). CWs are an ideal solution for reducing pollution of Nepal's sacred Bagmati river, and help to conserve it.

\begin{tabular}{|c|c|c|c|c|c|c|c|}
\hline S.N. & CW & $\begin{array}{c}\text { Flow } \\
\left.\text { ( } \mathrm{m}^{3} / \text { day }\right)\end{array}$ & $\begin{array}{l}\text { Total Surface } \\
\text { Area of the CW } \\
(\mathrm{m} 2)\end{array}$ & $\begin{array}{l}\text { Population } \\
\text { Equivalance }\end{array}$ & $\begin{array}{l}\text { Surface Area } \\
\left(\mathrm{m}^{2}\right) \text { per PE }\end{array}$ & $\begin{array}{l}\text { Surface Area }\left(\mathrm{m}^{2)}\right. \\
\text { per unit design } \\
\text { flow }\end{array}$ & Remark \\
\hline \multirow[t]{2}{*}{1} & Dhulikhel Hospital & 10 & 261 & 51 & 5.1 & 26.1 & In 1997 \\
\hline & & 40 & & 386 & 0.7 & 6.5 & In 2006 \\
\hline 2 & ENPHO & 1 & 15 & 9.8 & 1.53 & 15.0 & \\
\hline 3 & Kathmandu University Dhulikhel & 40 & 628 & 193 & 3.25 & 15.7 & \\
\hline 4 & Sunga, Thimi & 25 & 300 & 285.7 & 1.05 & 12.0 & \\
\hline 5 & Private residence, KMC Ward no. 15 & 0.5 & 6 & 8 & 0.75 & 12.0 & \\
\hline 6 & Teku Sepatge Treatment plant & 40 & 587 & 4685 & 0.13 & 14.7 & \\
\hline 7 & Malpi International School & 25 & 367 & 307 & 1.2 & 14.7 & \\
\hline 8 & $\begin{array}{l}\text { Sushma Koirala Memorial Plastic and } \\
\text { Reconstructive Surgery Hospital }\end{array}$ & 15 & 141 & 135 & 1.04 & 9.4 & \\
\hline 9 & $\begin{array}{l}\text { Staff quarter of middle Marsyangdi } \\
\text { HEP PST }\end{array}$ & 26 & 298 & 223 & 1.34 & 11.5 & \\
\hline 10 & Kapan Monastry & 17 & 200 & 146 & 1.37 & 11.8 & \\
\hline 11 & $\begin{array}{l}\text { Septage and Landfill Lechate } \\
\text { Treatement Plant }\end{array}$ & 110 & 2680 & $\mathrm{Na*}$ & $\mathrm{Na}$ & 24.4 & \\
\hline \multicolumn{8}{|c|}{$\begin{array}{l}\text { Source: Training Manual on Constructed Wetlands for wastewater treatment (UNHABITAT, Dhulikhel Municipality and ENPHO, 2007) } \\
\text { Constructed Wetlands Manual (UNHABITAT, 2008) }\end{array}$} \\
\hline & Average & & & & 1.6 & 14.5 & \\
\hline
\end{tabular}




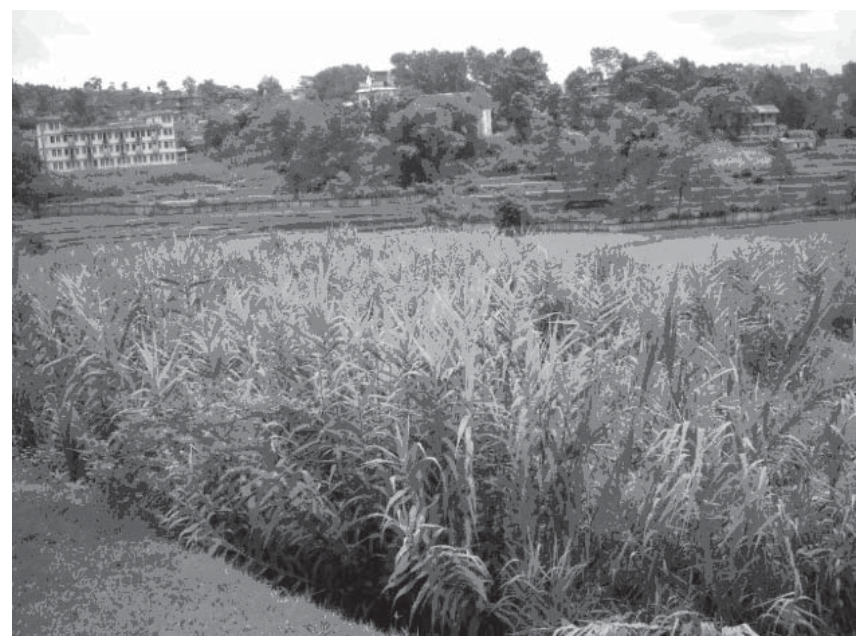

Figure 3. CW at Kathmandu University

\section{Conclusions}

Several physical, chemical and biological processes occurring within wetlands removes suspended solids (TSS, total suspended solids), organic compounds (BOD, biological oxygen demand), and chemicals (COD, chemical oxygen demand), as well as phosphorous, nitrogen, metals and pathogens present in wastewater. Water quality tests on wastewater effluents from various wetlands in Nepal have shown that TSS, BOD, COD are removed by more than $95 \%$. Similarly, coliform bacteria are also removed by $99 \%$.

Constructed wetlands arean appropriate technology for Nepal. Although this technology is not the over-all answer for the present wastewater problem, it is sufficient for periurban and rural areas. Nepal is characterized by an extreme topography. Therefore it is economically impossible to construct long sewer lines for the centralized treatment of wastewater. Decentralized wastewater treatment plants, like the constructed wetlands, are more economic. Land is always expensive in agricultural regions like Kathmandu valley, but compared to conventional wastewater treatment plants and sewer costs in it is still an economically reasonable decision to develop constructed wetlands. It is a simple technology that does not need much attention and know-how to operate it properly.

The reuse of treated wastewater helps save water. Together with the water collection technologies such as rainwater harvesting, this technology will be extremely beneficial for water resource management in Kathmandu Valley in the coming years.

Although the potential for the application of wetland technology in Nepal is enormous, therate of adoption of this technology for the wastewater treatment is not high. The reason for this could be limited knowledge and experience with this technology, its design and management.

Dibesh Shrestha and Shovana Maharajan arestudents of Interdisciplinary Water Resources Management at the Nepal Engineering College. Mr Shrestha is a civil engineer by profession and is associated with Akara Engineers \& Associates. Ms Maharjan has done Bachelors in Environment Science and has been associated with Environmental Resources Group as an Environmentalist for two years.

Corresponding address:

Dibesh Shrestha - dibeshshrestha@live.com,

Shovana Maharjan - shovanamaharjan23@gmail.com

\section{References}

Bhattarai, K.K, N.R. Khatiwada and P. Sharma, 2006, 'Use of horizontal flow constructed wetland for wastewater treatmant in Nepal', presented at the Seventh IWA Specialist Group Conference on Waste Stabilization Ponds Advances in Pond Technology and Management', 25 - 27 September 2006, International Water Association/Asian Institute of Technology, Thailand

Chhatwal, G.R., M.C. Mehra, T. Katyal, M. Satake, M. Katyal and T. Nagahiro, 1995, Environmental Water Pollution and Its Control, New Delhi: Anmol Publ. Pvt. Ltd.

Constructedwetlands.org, n.d., 'Back to nature, constructed wetlands for low-cost wastewater treatment and nature conservation'. URL: www.constructedwetlands.org/ cw/ index. $\mathrm{cfm}$.

ENPHO, 2007, Training Manual on Constructed Wetlands for Wastewater Treatment: For Municipal Technicians on Planning, Designing Operating and Maintaining Constructed Wetlands for Wastewater Management Systems, Kathmandu, Nepal: Environmental and Public Health Organization.

Maharjan S., 2007, Efficiency of Constructed Wetland Located at Various Locations, BSc Thesis, Kathmandu University, Dhulikhel, Nepal.

Melamchi Water Supply Project, Work Plan and Annual Progress, 2009

Metcalf \& Eddy, Inc., 1991. Wastewater Engineering; Treatment Disposal Reuse, New Delhi: Tata McGraw-Hill.

Simeral, K.D., 1998, 'Using constructed wetlands for removing contaminants from livestock waste water', A-5-98. Columbus, Ohio: Ohio State University Fact Sheet. URL: http:/ / ohioline. osu.edu/a-fact/ 0005.html.

Toolbase Services, 2007, Constructed wetlands for wastewater treatment: An environmental wastewater treatment solution that relies on marsh plant roots for filtration'. URL: www. toolbase.org/ Home-Buildging-Topics/ Land-Use/ constructed wetlands.

UNHSP, 2008, Constructed Wetlands Manual, Kathmandu: United Nations Human Settlements Program/UN-HABITAT Water for Asian Cities Program Nepal. 